\title{
СОВРЕМЕННАЯ РУССКАЯ ПАРАДИГМАТИКА НА УРОВНЕ СИСТЕМНЫХ СВЯЗЕЙ СЛОВ (НА МАТЕРИАЛЕ СИНОНИМОВ)
}

Глотова Т. О. Сучасна російська парадигматика на рівні системних зв'язків слів (на матеріалі синонімів).

У статті розглянуто сучасну російську парадигматику на рівні системних зв'язків слів. Системні відношення особливо виразно проявляються в лексиці. Відношення лінгвістичних одиниць на основі загальної ознаки виражені в синонімії. Словники синонімів є важливим джерелом відображення лексичної системи сучасної російської мови. Синоніми відрізняються відтінками значень, стилістичним забарвленням і виконують ряд функцій у мові.

Ключові слова: парадигма, синонімія, лексикографія, системні відношення, сполучуваність.

Глотова Т. А. Современная русская парадигматика на уровне системных связей слов (на материале синонимов).

В статье рассматривается современная русская парадигматика на уровне системных связей слов. Системные отношения особенно ярко проявляются в лексике. Отношения лингвистических единиц на основе общего признака выражены в области синонимии. Словари синонимов являются важным источником отражения лексической системы современного русского языка. Синонимы различаются оттенками значений, стилистической окраской и выполняют ряд функций в языке.

Ключевые слова: парадигма, синонимия, лексикография, системные отношения, сочетаемость.

Glotova T. A. Paradigmatics in system lexical relations in modern Russian language (on the basis of synonyms' research)

The article deals with paradigmatics in system lexical relations in modern Russian language. System relations are most notably explored on vocabulary level. The correlations among linguistic units which are based on common component are expressed in synonyms. The dictionaries of synonyms reflect the functioning and development of lexical system in modern Russian language. Synonyms are different in their shades of meaning, stylistic nuances, and perform a set of functions in language.

Key words: paradigm, synonymy, lexicography, system relations, compatibility.

На современном этапе развития языкознания неоспоримым признается факт исследования языка как строгой, организованной системы, т. е. закономерно согласованного и взаимосвязанного единства сторон, частей и единиц. Особенно ярко системные отношения проявляются в лексике. Одной из основных задач, которые призвана решать лексикология, является рассмотрение различных видов системных отношений, существующих внутри различных групп лексики, установление тех объективных показателей, которые объединяют слова друг с другом.

Для объединения слов важнейшим критерием служит наличие (или () Т. А. Глотова, 2013. 
отсутствие) как сходных, так и различительных признаков в их семантической структуре. В современной лингвистике подобные отношения названы парадигматическими, и под парадигмой понимается «любой класс лингвистических единиц, противопоставленных друг другу и в то же время объединенных по наличию у них общего признака или вызывающих одинаковые ассоциации, чаще всего - совокупность языковых единиц, связанных парадигматическими отношениями» [2, с. 366]. Любая парадигма на любом уровне языковой структуры представляет собой совокупность вариантов, объединенных для них общим устойчивым инвариантом и закономерно чередующихся в процессе функционирования языка.

Отношения лингвистических единиц, объединенных по наличию у них общего признака, ярко характеризуются в области синонимии и являются подтверждением необходимости всестороннего анализа данной лексической категории. Системность лексики находит свое отражение и в словарях, где представлены основные лексико-семантические группировки слов русского языка. Современная лексикография - это активно развивающаяся область языкознания, стремящаяся достигнуть более полного системного описания лексики. Примерами тому могут служить словари синонимов А. П. Евгеньевой, 3. Е. Александровой, Н. Абрамова, К. С. Горбачевич, В. Н. Клюева и др.

Синонимы как яркая лексическая категория позволяют отчетливо представить системные отношения на уровне состава языка. Так, два и более лексических синонима, соотносимых между собой при обозначении одних и тех же явлений, предметов, признаков, действий и т. п., образуют в языке определенную парадигму, иначе называемую синонимическим рядом. Например, для обозначения действия, приводящего в состояние нервного напряжения, подъема, в русском языке используют синонимический ряд возбуждать - волновать, будоражить, взбудораживать, взвинчивать, электризовать, наэлектризовать.

В синонимический ряд входят слова и фразеологические обороты с максимальной близостью значений, поскольку они являются пределом тематического дробления слов, объединенных какой-либо семантической общностью. Например: откровенно - искренне (искренно), чистосердечно, начистоту, не таясь, со всей откровенностью, прямо, открыто, без утайки, напрямик, прямиком (разг.), начистую (прост.), положа руку на сердие; как на духу, как перед богом (уст.). Таким образом, парадигматику представляет сам синонимический ряд, где противопоставлены доминанта, слово, которое является как бы лейтмотивом всего ряда и определяет его основной характер, и остальные слова, которые, кроме основного значения, выражают дополнительные семантико-стилистические оттенки, например: сложсный - труднылй, запутаннылй, замыслловатьій, хитроумнылй, головоломный, мудреный, хитрый, каверзный (разг.), заковыристый (прост.) и др.

Вопрос о лексических синонимах существует в филологической 
науке с момента ее зарождения и продолжает сохранять свою остроту до настоящего времени. Установлено, что синонимия широко присуща почти всем категориям языка, обладающим в той или иной мере семантической определенностью или смыслом: морфемам, словам, фразеологизмам и т. п. Среди общих проблем лексической синонимики первостепенное значение занимает вопрос установления критериев синонимических отношений (П. С. Александров, И. В. Арнольд, М. В. Никитин и др.). К таким критериям, помимо общности выражаемого понятия, семантической тождественности, семантической близости и др. принадлежит и так называемая взаимозаменяемость синонимов, которая рассматривается как их основной признак, или как прием, способ, метод выделения синонимов, служащий основой для их характеристики. Однако следует отметить, что о заменах и взаимозаменах возможно говорить лишь в том случае, когда мы имеем дело с какими-либо контекстами. Так, в решении проблемы лексических синонимов представляется чрезвычайно важным разграничить вопрос о синонимах в лексико-семантической системе языка и вопрос об их употреблении, т. е. о функциях и роли синонимов в речи (в контексте). В определенной степени вопрос о синонимах языка и речи решает словарь синонимов. Синонимические связи пронизывают лексическую систему, сопрягаясь и пересекаясь с иными видами отношений лексических единиц. Bсе это, конечно же, должно найти адекватное отражение в словаре. Словари синонимов являются важнейшим источником отражения лексической системы современного русского литературного языка. Их цель - упорядочить семантическую языковую систему, сделать оптимальным и обусловленным выбор идентичных языковых средств.

Синонимами обычно считаются «слова, которые имеют одно и то же лексическое значение, различаясь лишь оттенками значений, экспрессивной окраской и принадлежностью к тому или иному стилистическому слою языка, и которые имеют хотя бы частично совпадающую сочетаемость» [2; 3]. Например: бесчинствовать - буйствовать, буянить, бушевать (разг.), куролесить (прост.), чернить (уст. прост.); скандалить - дебоширить, скандальничать (разг.), бузить, поднимать бучу (прост.). Как видим, словарь включает два синонимических ряда слов с близкими значениями. Помимо различий в оттенках значений и экспрессивной окраске, синонимический ряд отражает принадлежность к определенному стилю речи.

В словарных статьях словарей синонимов обычно не раскрываются значения слов-синонимов, их употребление не иллюстрируется примерами. Словари преследует практические цели: дать в каждом синонимическом ряду определенный набор синонимов, из которых пишущий в зависимости от цели своей работы может извлечь нужный, наиболее подходящий для точного и яркого выражения материал. Вместе с тем, чтобы помочь читателю в правильном выборе необходимого слова, автор часто ис() Т. А. Глотова, 2013. 
пользует краткие пояснения и пометы к отдельным синонимам или их группам, указывающие на возможность сочетаемости. Например: брак супружество, брачный союз; брачные (или супружеские) узы; узы Гименея (уст. поэт.) / для мужчины: женитьба / для женщины: замужество.

Некоторые синонимы указывают на дифференциацию значений, например: несчастье - драма, трагедия, невзгоды, бедствие. Дифференциация экспрессивно-стилистической окраски наблюдается почти в каждом синонимическом ряду, например: несчастье - напасть (разг.), бездолье (прост.). Многие синонимы указывают на сферу употребления, например: несчастье - недоля (уст. и нар.-поэт.), злосчастие (уст.), казнь египетская (уст.). Таким образом, роль контекста, выявляющего значение и окрашенность слова, играет в Словаре сам синонимический ряд и его доминанта.

Словари синонимов раскрывают все богатство лексической системы русского языка. Так, в «Словаре синонимов русского языка» под общей редакцией Л. Г. Бабенко слова располагаются не в алфавитном порядке, а представлены в составе групп, в которые они объединены по смыслу на основе общего выражаемого понятия. Например, лексика цвета (голубой, аметистовый, кровавый, желтеть, синеть, краснота, белизна и др.), движения (бег, полет, идти, ползти, мчаться и др.), природы (заросли, трава, клевер, прорастать, тепличный и др.) [4].

В 2003 году вышло второе, исправленное и дополненное издание «Нового объяснительного словаря синонимов русского языка» под общим руководством Ю. Д. Апресяна. Издание представляет словарь активного типа, основанный на следующих семи принципах: активность, системность, интегральность, ориентация на отражение «наивной» картины мира, использование специальных метаязыков для описания существенных свойств лексем, комбинирование методов корпусной лексикографии и экспериментальной лингвистики, идеографичность [3]. Большинство синонимических рядов в Словаре отобраны по принципу антропоцентричности. Например, синонимы душа и сердце приводятся для обозначения «невидимого органа чувств и предчувствий, находящегося где-то в груди человека»Ср.: Дуиа в нем встрепенулась. Сердце переполняла нежность. В Словаре отмечено, что синонимы данного ряда «входят в пласт слов, обозначающих невидимые сущности внутри тела человека» [3, с. 302].

Рассмотрим подробнее системные связи на материале «Словаря синонимов» под редакцией 3. Н. Александровой [1]. В данном издании в качестве синонимов могут помещаться отдельные слова, однокорневые доминанте, например: вода - водица, дрожь - дрожание, вычеркнуть зачеркнуть, вытираться - обтираться и др. Намного продуктивнее разно корневые синонимы. Именно они интереснее для наблюдения. Например: вернылй - преданнылй, постоянныци, неизменнылй, приверженнылй; ответить - откликнуться, отозваться, отпарировать (резко: отрезать, 
отрубить, огрызнуться (разг.) и т. п.

В синонимическом ряду, помимо отдельных слов, отмечены сочетания служебных и знаменательных слов, выступающие в той же синтаксической роли, что и доминанта, например: долго - до бесконечности, беспрепятственно - без помех, без задержки и т. п. В качестве синонимов выступают лексикализованные сочетания, обозначающие единое понятие, например: авиация - воздушный флот; глазник - глазной врач, а также: железная дорога - железка, чугунка; обходной лист - бегунок. В качестве синонимов к доминанте могут быть представлены фразеологизмы, например: бедствовать - не иметь ни гроша за душой, мыкать горе (или век, жизнь), биться как рыба об лед, едва (или еле, кое-как) сводить кониь с концами, перебиваться с хлеба на квас, свистеть в кулак и т.п.

Таким образом, «Словарь синонимов» 3. Е. Александровой показывает характерные признаки синонимов, отмечает отношения между синонимами в синонимическом ряду, служит наглядным отражением лексической системы современного русского языка и располагает большим лингвистическим материалом для наблюдения.

Лексическая синонимия тесно связана с явлением многозначности. Разные значения слова, а также их оттенки составляют так называемую семантическую структуру многозначности и служат ярким примером проявления системных связей внутри одного слова.

«Словарь синонимов» достаточно широко отражает полисемию. Например, в разделе на букву «Е» помещено 83 слова, из них многозначных 17. В разделе на букву «Ж» - 178 слов, из них многозначных - 55. Учитывая, что характер внутрисловных семантических связей в языках неодинаков, можно считать многозначность одним из ярких признаков национальной самобытности лексики.

«Словарь синонимов» 3. Е. Александровой имеет важную особенность разграничения значений многозначного слова и дифференциацию синонимов в соответствии с такими значениями. Это выгодно отличает данный словарь от предшествующих русских синонимических словарей, в которых при многозначных словах синонимы давались нерасчлененно. В Словаре 3. Е. Александровой строго прослеживается принцип: если слово может выступать в качестве доминанты в нескольких значениях, то соответствующие синонимы помещаются в одной словарной статье. Если же в каких-то значениях слово не может являться доминантой, то в словарной статье дается ссылка на ту доминанту, по отношению к которой слово в данном значении выступает в качестве периферийного члена ряда. Например, слово играть в «Словаре синонимов» отмечено как многозначное: играть 1. исполнять, музицировать (уст.) и др., 2. в спектакле: исполнять роль, представлять, 3. в карты: резаться (разг.), 4. см. резвиться, 5. см. сверкать. Как видим, слово играть имеет в словаре три значения, которые () Т. А. Глотова, 2013. 
семантически связаны. В четвёртом и пятом значениях, по мнению автора, слово играть не может служить доминантой, а выступает в качестве синонима других словарных статей: резвиться и сверкать.

Рассмотрим, какие многозначные слова-доминанты привлекают составителя словаря. Это могут быть слова с двумя-тремя значениями. Например: обычность - 1. обыкновенность, 2. заурядность, напряжсенность драматичность и др., 2. интенсивность, 3. неестественность.

Отмечены случаи, когда доминанта объединяет восемь, десять и более значений. Например, у слова полный в Словаре приводится восемь значений, а у слова поднять зафиксировано десять значений.

3. Е. Александрова, отмечая огромную роль многозначности, подчеркивает, что в русском языке «сложно переплетаются прямые и переносные значения многих слов» [1, с. 7]. Однако автор не только точно и последовательно отражает значения многозначного слова в синонимических рядах, но и помогает определить способы развития производных значений. На примере словарной статьи с многозначным словом-доминантой можно проследить развитие многозначности и способ переноса значений. Например, на словарной статье слова жить можно отчетливо проследить перенос значений по сходству функций: жсить - 1. существовать..., 2. вести образ жизни / благополучно: здравствовать / неблагополучно: скрипеть (разг. шутл.)..., 3. кормиться, содержать себя...

Первые три значения объединены по сходству биологических процессов существования человека. 6-е значение глагола жить - увлекаться. С. И. Ожегов данное значение употребляет с пометой переносное. Синонимы к нему - интересоваться / сильно: гореть, отдаваться цееликом. Это метафорический перенос на сходстве душевных порывов человека.

Метафорический перенос на сходстве функций можно проследить на ряде примеров. У слова крах в первом значении синонимы банкротство, несостоятельность. Второе значение Словарь маркирует пометой переносное - провал, неудача. Синоним крушение объединяет оба значения многозначного слова.

«Словарь синонимов» помогает выявить метафорический перенос по сходству формы. Например: слово ветвь в основном, первичном значении - это ветка (дерева). Во втором, производном, значении - это ответвление. В словарной статье ответвление находим: ветвь / железнодорожной линии, ветка / реки: рукав.

Таким образом, метафорический перенос, отраженный в «Словаре синонимов», отчетливо выявляет ту взаимосвязь, которая наблюдается в лексике, когда на фоне одних свойств, качеств, признаков проявляются другие.

Примеры «Словаря синонимов» раскрывают и перенос наименований по смежности внутри многозначного слова. Рассмотрим словарную статью слова-доминанты стихи. В первом значении - поэзия, т. е. 
стихотворное художественное творчество, отличное от прозы. Во втором значении Словарь отсылает читателя к статье стихотворение, т. е. небольшое поэтическое рифмованное произведение. Таким образом, в словарной статье мы видим как целое- поэзия вообще, так и часть целого - одно стихотворение.

Метонимический перенос, когда показаны процесс и результат этого процесса, можно отметить на примерах типа захоронение - 1. см. погребение (т.е. погребальный обряд, похороны), 2. см. могила - т. е. яма для тела умершего, а также насыпь над ней.

По замечанию 3. Е. Александровой, слова связаны друг с другом настолько сложными и многосторонними связями, что любая группировка их по значениям неизбежно является не единственно возможной. Вероятно, этим можно объяснить неточности, отмеченные нами в Словаре. Например: стиль - 1. о творчестве: жанр, 2. в литературе: слог, язык. Как видим, значения семантически разошедшихся слов даны в одной словарной статье. В одной словарной статье помещается явная омонимия. Например: молодец - 1. похвала. 2. см. юноша. В данном случае речь должна идти об омографах молоде́u и мо́лодец..

Итак, наблюдения над материалом «Словаря синонимов» показывают, что между значениями многозначного слова существует определенная семантическая связь. Это дает основание считать их значениями одного и того же слова в отличие от значений словомонимов. Эта связь может основываться на том, что в значениях обнаруживаются общие семантические элементы. В случае разрыва или полной утраты семантических связей между разными значениями появляется возможность для названия уже известным словом совершенно иных понятий, предметов и т. д. Это один из способов развития новых слов-синонимов.

Таким образом, словари синонимов, являясь важнейшим источником отражения лексической системы современного русского языка, упорядочивают семантическую языковую систему, делают оптимальным и обусловленным выбор идентичных языковых средств. Словари синонимов - важный источник для анализа системных отношений в лексике, одной из которых является многозначность. Синонимы внутри синонимического ряда, маркированные лаконичными авторскими комментариями, позволяют определить перенос наименования по сходству различных признаков, т. е. метафорический перенос, и по смежности - метонимический перенос.

Синонимы справедливо считаются показателем богатства, гибкости и развитости языка. Различаясь оттенками значения и стилистической окраской, синонимы выполняют в языке целый ряд функций: способствуют точности и ясности высказывания, фонетически разнообразят речь, обусловливают богатство стилей устной и письменной речи. 


\section{Литература}

1. Александрова 3. Е. Словарь синонимов русского языка / 3. Е. Александрова. [11-ое изд. перераб. и дополн.]. - М. : Изд-во «Русский язык», 2001. - 568 с.

2. Лингвистический энциклопедический словарь / Под ред. В. Н. Ярцевой. - М. : Сов. энцикл., 1990. -682 с.

3. Новый объяснительный словарь синонимов русского языка / [второе издание, исправленное и дополненное под общим руководством академика Ю. Д. Апресяна]. М. : Издательство Школа «Языки славянской культуры», 2003. - 1418 с.

4. Словарь синонимов русского языка / Под общей редакцией проф. Л. Г. Бабенко. М. : АСТ, Астрель, 2011. - 688 с. Доступ онлайн http : //lib.rus.ec/b/446448/read 